\title{
Picturing vision
}

\section{The interconnectedness of mental and visual images}

\author{
Eva SchürmanN
}

Aвstract - Kant taught us to think of the faculty of imagination as an ingredient of perception. Vision, thus, is not only opened to the present but also to the absent, for instance through expectations or memories. Our ways of seeing are literally formed by normative presumptions and culturally predetermined ideas. This makes visual perception a sort of an image-making activity in the context of a practice. It is the practice that regulates what can be perceived in which way or what is overlooked. As an activity it is neither solely a pure construction of individual viewpoints, nor a pure representation of the physically present world. Rather, it is the result of the reciprocal tension between the perceiver and the perceived.

\section{A holistic notion of seeing}

In this article I propose a holistic rather than a naturalistic approach to philosophy of perception. In the philosophical tradition seeing is treated mostly in terms of an epistemological framework. The idea of perception as an activity re-emerged in the context of enactivism and embodiment studies. My claim is that we have to go into further details here by qualifying the type of activity as an image-making practice. By image, though, I do not mean mimetic representations, and by representation I certainly do not mean copies. Pictorial representations are the result of the mind's capacity to imagine something that is not necessarily physically present.

Causal conceptions of visual perception cannot explain why perception is not determined by the perceivable world but can function in a very individually different manner. Scientific and naturalistic explanations of the capacity of vision leave unexplained the vivid experience how visual perception involves mental activities such as normative attitudes, expectations and emotions. Visual perception cannot be reduced to sensory experience.
I proposed in my book on seeing as doing (Schürmann 2008) a notion of practice that owes a lot to two very different thinkers, namely French phenomenologist Maurice MerleauPonty and Ludwig Wittgenstein, in order to explain perception as action in situated cultural collective contexts.

It may be fruitful to remind ourselves that the capacity of imagination is deeply connected with vision, as it is related to interpretation, judgement and discernment. By conceiving of it as cultural practice, I mean that seeing is an activity through which we disclose the sensually perceptible world. As I intend to show below, the interconnectedness of impressions, ideas, perceptions and images characterises the way the mind deals with the world and the other. Mental images ${ }^{1}$ start with visual images and visual images are informed by mental activities.

1 For a recent overview on the mental imagery debate from a transdisciplinary perspective see Sebastian Gerth (2016) and Klaus SachsHombach (1995). 
Neither an understanding of retinal impulse reception nor of neuronal information processing helps to explain the curious paradox that seeing is, on the one hand, a proven means of orientation, of acquiring information and interacting with others, while being, on the other hand, a personality-specific way of perceiving reality dependant on individual and cultural variations. In general, a type of assertive seeing that is regarded as a non-problematic instance of epistemic perception, whereas all more complex cases of seeing something as something are labelled interpretative deduction, or, worse still, thought of as mere metaphorical talk about vision.

A philosophical notion of vision has to explain why we all have divergent perceptual experiences, although the same physiology and the same physical visibility in a certain time and at a certain place should determine what we see. At the same time, we do not live in perceptually private worlds either. It has to follow that seeing is neither pure representation of a physically present world nor the pure construction of individual viewpoints, although it nevertheless contains portions of both.

This can only be explained by admitting that seeing takes place in the context of cultural customs and personal preferences. In seeing, the particular dispositions of the individual as well as social and historical circumstances transcend seeing itself and make it the constitution of a viewpoint.

\section{Iconicity}

Yet, the ways of seeing are at first immanent to consciousness and free from objectification. How perceivers represent something to themselves still has to be represented outwardly, through language or through pictures. This occurs paradigmatically in art, where a painter may bring a view of something into an image, that means: a way of looking at the world. In this way an otherwise invisible movement becomes expressed in a sensibly perceptible way. What gets represented is how the artist saw what he or she saw. For their part, representations are ways of seeing that have become objects. Like a personal style of handwriting, an individual perceptual style and a personal visual ethos could explain the space of free choice and the possibilities of seeing differently without which perception would not be world disclosure. The aspect of style is not a mere formal determinant, it is a moral factor, which is manifested in the ethos and habitus of the seeing individual, whose biography and mentality structure the possibilities of perceiving something creatively or conventionally. For vision's capacity for world disclosure the decisive characteristic is its iconic nature. We can take recourse to Immanuel Kant, who posited the imagination, conceived as the 'faculty of images', as an ingredient of perception (Kant r 999: Ar 2 I). No theory of perception can do without such an image-making element. The strange thing here, though, is that something is at the same time found and invented.

Now, images are not to be construed as replicas of data otherwise present, but rather as indefinitely prolongable interactive processes enacted between mirroring and creation. In this in-between space, what can be seen and how it can be seen is decided by a variable and presumably never entirely determinable combination of perception and imagination, seeing and blindness, addition and subtraction, look and view.

\section{Mediality}

Seeing as purpose-serving means to an end implies the use of the eyes as an object-like tool like a telescope or a magnifying glass - classical instruments for mediating perception. ${ }^{2}$ This type of seeing is entirely different from those

2 Interesting material on this topic can be found in the anthology by Erika FischerLichte et al. (2001). 
cases where we see other persona and are ourselves visible as we move around in the world, looking involuntarily around. Perception in this case is less active and more like the element we find ourselves in than a tool we make use of. ${ }^{3}$ As medial occurrence, seeing is a way of relating to something that at the same time absorbs us.

There is a striking similarity to the way language is constituted. 4 Where language is something we move about in and at the same time the means by which we communicate, so too is perception characterised by a thoroughly paradox duplicity. Neither the world nor the other is immediately given but rather mediated and generated by language and perception.

While the concept of action requires an actor, the notion of mediality rather expresses the character of something happening. Now seeing always entails something of both. It can be both functional and directed at ends and also casual and involuntary. It can focus on something or be captured by something. Practice is itself the umbrella term for these logical paradoxes. In practice, the medial character of seeing can interact with its character as action. The odd medial location of practice between subject and object is precisely its specific feature.

Because seeing is always a movement between two poles, between consciousness and world, the sensory and the mental, reception and spontaneity, it must itself be a mediating movement. It always proceeds as a balancing act that can lean towards at least two different sides, or rather originate from two different sources. The paradox of perceptual practice is that the physical world as such is not an object, but rather the result of a process conditioned by individual and socio-cultural criteria.

3 As Donald Davidson puts it, 'We don't look through our eyes, but with them' (Davidson I 997: I 8).

4 As Wilhelm von Humboldt (1973) pointed out by distinguishing ergon and energeia.
The concept of practice provides an alternative to the scheme of subjectivity versus objectivity by clearly showing the way both are mediated by their situation in contexts and forms of life. Practice means being visible to oneself and to others, acting and speaking in the world as a place we inhabit collectively, not infrequently fighting about its sense as a whole. We have incidentally seen that seeing can largely be divided into a functional-pragmatic and a self-purposive dimension, whereby the many and varied applications of visual perception can be systematically classified.

\section{Negativity}

To claim that seeing is a performative practice also implies taking into account the negative side of the process. Seeing something entails blocking out other things. A figure can only be focused by making the background vanish. The practice of seeing systematically involves types of habitual blindness; no longer seeing familiar things or overlooking things we are accustomed to interpret schematically as well as overlooking things. The negativity of vision is what makes its essential creativity comprehensible. If someone, for instance, enters a room where they are used to seeing a piano, the piano is no longer perceived in the fullness of its sensory apparition. What is thus no longer perceived might still present to echo in every act of vision. The same applies to peripheral vision. This helps explain how our perceptions can diverge from what is given to visibility. What we see and, more importantly, what we do not see result from acts of selection that individualise the meaning of the seen.

Like the negativity of the visible, the negativity of seeing must be subdivided. To overlook something is different from being blinded by imaginings. Supplementary seeing is woven into the invisible differently from how selective seeing is. The former not only completes a seen object by adding its other sides, but also adds 
inventions, interpretations and imaginings. We not only do not see what we do not see, we also do not see that we do not see it (Foerster 1985).

As William T. J. Mitchell has shown, even if an innocent eye existed, it would in no way see 'objectively the way things are'.

When we try to postulate a foundational experience of 'pure' vision, a merely mechanical process uncontaminated by imagination, purpose, or desire, we invariably discover one of the few maxims on which Gombrich and Nelson Goodman agree: 'the innocent eye is blind'. The capacity for a purely physical vision that is supposed to be forever inaccessible to the blind turns out to be itself a kind of blindness. (Mitchell I986: I I 8)

Even if pure perception were to exist, which both Ernst Gombrich and Nelson Goodman naturally deny, it would be partially blind to the possible social meanings of the seen.

\section{Metaphors}

Verba videndi in many languages show an inseparability of seeing and thinking, and a deep intertwining of sight and insight. Words like view-point, German Ansicht, French point de vue, and Italian considerazione express the unity of an act of visual perception directed at both the visible and the invisible. The entire metaphor of understanding as seeing suggests this inextricability of the sensory and the mental. 5 The vocabulary of mental acts of understanding points in many languages to a visuality of cognition and to intelligibility in perception. This begins presumably with the Greek term $\theta \varepsilon \omega \rho$ í $\alpha$ for a seeing at once sensory and mental, continues with the Latin perspicere, the French voir in $s a$-voir, with the double meaning of the Ital-

5 Yet the same is true of haptic connotations such as to grasp. ian guardare, with the meanings to guard and to take care of, and to the English 'I see what you mean'. In the Greek, the perfect of *cil $\delta \omega$ 'I see' is oĩda, 'I have seen' and is equivalent in meaning to 'I know'. Knowledge is construed as the result of having seen. This explains the weight of eyewitness accounts and visual demonstrations. Far beyond figurative speech it articulates a systematic connection between sight, insight, understanding, interpretation, opinion formation, being convinced and knowledge.

With Hans Blumenberg, seeing can thus be designated as an absolute metaphor, and that the verba videndi stand in where logic fails (Blumenberg 2010: 3). This befalls thought where it attempts to explain the relation between sight and insight. No well-defined 'literal' term for seeing can be isolated from metaphorical talk of seeing. Rather, the figurative speech indicates a problem the unavoidability of which demands attention 6 since it signals that reducing the sense of sight to perception is to artificially isolate only one part of seeing from a holistic act. The metaphoricity of the term itself offers a way to render seeing manifest. To speak of seeing 'with other eyes', of overlooking or oversight, of ways of looking at things, is not merely a way of speaking that could be translated into a clearer language or replaced with non-pictorial terms. Rather, seeing is the literal movement of in-sight, which can be grasped neither purely aisthetically nor mentally. It is an aisthetic way of world disclosure, the aesthetic and imaginary ramifications of which require investigation in individual cases. For a holistic understanding of perception, 'pro-viding' or 'seeing through' something are not merely figurative descriptions. Nor are they basic or simple perceptual acts, since the assumption of such acts is itself mixed up

6 Ralf Konersmann (I 99I) has played on similar notions regarding the metaphor of the mirror. The fleeting nature of the image makes it appropriate as a representation of the intangibility of a subjectivity that eludes itself. 
with a misleading use of terms. Such activities are at once aisthetic (in the sense of literally perceivable) and cognitively epistemic, meaning that they are bound to the use of the eyes without exhausting themselves therein.

There exist isolated cases of metaphors of seeing. In order to 'see' what someone means I do not need to see something in front of me. The act or state of 'respecting' someone is not itself an act of perception. Yet in the context of the many-layered interconnections of the aeisthetic and the mental such relatively clear-cut cases are rather the exception than the rule. It is much more common to see that someone wants to speak, or the way someone is looked up to hinges on the way she looks.

This cluster of verba videndi is genuinely metaphorical in the sense that they cannot be translated back into literal meanings and do not provide merely rhetorical ornamentation but rather disclose a relational whole.

Subsequently, seeing invisible things 'in the mind's eye', 7 that is to say, seeing what can only be known or wished, is precisely not an exclusively mental activity but rather a hybrid of aesthetically and mentally occasioned ways of seeing.

Let us come back to the notion of image at work here.

As I said, the iconicity of seeing can be regarded as grounded in this faculty, which is, according to Kant, not only 'a necessary ingredient of perception itself' (Kant I 999: Ar 2 I) but also the 'power of representation' (Kant 2002:

7 I avoid this expression as far as possible in order not to fall back into the division between physical and mental seeing. The point here, however, is to refer to a term responsible for the entire tradition of the idea of the given. It is indicative of the intricacies of the problem that even authors like JeanPaul Sartre (2004) and Colin McGinn (2004) use the term although they postulate the cooperation of the mental and the visual in practice.
$\S \S 17,23,49,62)$. Arguably, it would also be possible to speak of fantasy. ${ }^{8}$ What is meant is that seeing must maintain an intensive relation to the powers of imagination. In order to illuminate this relation, a concept of the image must be worked out that helps to explain the generation of images in perception as well as their expressive function. We can understand how seeing is capable of extending beyond the disclosure of facts to become an act of configuration.

The theoretical separation between perception and imagination is undermined in practice. A recurring pitfall for theoretical explanation is that describing the correlation between perception and presentation, sight and imagination separates them whereas they are fused in practice. Reference to 'interplay' and 'interlocking' between imagination and perception should not be understood as forgetting the insight that they are inseparable. They are instead the attempt to display the difficulties in grasping the protean interactions in between them.

8 The terms are all polyvalent and their use varies according to author, language and epoch. Samuel Taylor Coleridge (I 8 I 7 ) distinguishes between imagination as a creative faculty and fancy. The German term Einbildungskraft is translated into French as 'imagination', meaning a Vorstellungsvermögen, translatable as faculty of representation. This is an important shift in meaning. The plural Phantasien (fantasies) usually signifies the content of Vorstellung, presentation or representation, while German Phantasie in the singular means the faculty or power, Einbildungskraft. As Dietmar Kamper (I 98 I: I 2) has pointed out, the term Phantasie occurs three times in the Western tradition: 'First, as "material" ... for dreams ... and civilisations; second, as transcendentally efficient order for knowledge; third, as the reviled minor faculty of daydreaming that mainly assumes compensatory functions.'The multiplicity of the term is also manifest in the various disciplines concerned with it: psychology, psychoanalysis, philosophy, epistemology, aesthetics, mythology and, in the case of Cornelius Castoriadis, political theory. 
Kant and Johann Gottlieb Fichte attribute a truly impressive power to the imagination (Fichte 1889: 187). We cannot overestimate the extent to which it participates in all processes of world disclosure. All perceptions of self and world are inhabited by the affective power of images, ${ }^{9}$ by an orchestral range of feelings, desires, projections and stereotypes. 10

The images that emerge from the performative interplay of imagination and perception are not solid givens but infinite productions. The intermingling of the invisible into seeing does not result in externally visible objects. Rather, the products of imagination must be regarded as processes of construction 11 involving perception and image making rather than as results. The stress is on the active character of the process that consists in a performative activity. This process remains unfinished as long as seeing remains open to possibilities of seeing differently. The resulting images can still become mortified, stereotypical and clichéd, since they involve determination and exclusion. However, the important point is that such images are made possible by both perception and imagination and are consequently attributable neither to sensibility nor to sense alone.

Perceptions of world, the self and others are influenced by images of wishes and fears, which, as we will see, in an extreme case like Don Quixote, qualify as insanity and not perception. In general, however, the imaginary comes mixed with things sensually present. ${ }^{12}$

9 Interesting in this regard is the empirical study by James Elkins (200I).

10 On the psychological and affective aspects of interactive percept see the collection by Gertrud Koch (1995).

11 More on this can be found in Kamper 1998: 203-I3. Further readings in the same spirit are found in the collection by Gerd Schäfer and Christoph Wulf (I 999).

12 'The imaginary perhaps only attains to pure presence on madness' (Iser I99I: 3 I4).
As a picture-making creature, as homo pictor (Jonas I973: 226-47) and animal symbolicum (Cassirer I 944), the human discloses the world in a way that cannot be divided hierarchically into separate domains of competence. Attaining a mental image of an object can involve deliberately ignoring the surface, but it can also involve being blinded by the surface and overlooking what is concealed beneath it. In both cases seeing operates at the intersection of the visible and the invisible.

\section{Perceptual images}

Perceptions and images are not as different as two entirely unrelated things, but they do not converge without difference either. There seem to be equally plausible reasons for their inseparability as there are for their separation. To put it concisely, it is their connectedness that presupposes their distinctness.

Images develop against the background of what has been previously perceived and the perceptions themselves come about in correspondence to the criteria of images, schema and representations, that is, in the temporal horizon of previous experience and expectations derived from that experience. A representationalist posing of the question of how much such images can 'correspond' with their referents is answered from the point of view of performative practice not as a dual copy relation but rather as the iterative structure of references referring to references, interpretations interpreting interpretations. This does not mean they are empty signs without a material basis. The world is the interpreted world. We cannot say what it would look like if it were not interpreted, i.e. mediated by symbols, language and signs. But interpretations are not arbitrary constructions, but rather conditioned and regulated by the context of the practical. 


\section{Image without model}

And yet, it would be no remarkable finding that perception is necessarily reflected, interpreted and mediated if that served only to revitalise constructionist concepts. Under the conditions of a performative concept of perception, however, this result can be specified to paradoxically render the mediations both responsive and spontaneous, fictional and perceptual. Edmund Husserl's lucid qualification of the image as 'perceptual figment' (Husserl 2006: 6r 2) is a just characterisation also for images in perception, which then become aisthetic-aesthetic acts of mediation between self and world. Once again the model of seeing as practice both requires and enables a break with the logic of the disjunction between subject and object, since the paradoxical structure of perceptual-fictive mediations can be grasped neither with constructionist nor with realist concepts.

Perceptual-fictitious mediations produce images of self, world and others that are not object-like. As problematic as the concept of mental images may be for epistemology (Kosslyn 1980), 13 the non-object images that someone makes of themselves and the world out of perceptual and imaginary images can only be grasped as performative formations occasioned aisthetically, in which the person is unable to get away from evaluative ways of viewing the world.

If the viewer and the visible are only given in and mediated by their performative mutual relatedness then the perceptual image cannot be a mimetic representation. To put it with the words of French philosopher Jean-François Lyotard: 'The concept of a picture (eikon) of facts condenses within itself the metaphysical illusion, the reversal or prejudice that phrases come after facts' (Lyotard 1988: 79). This illusion is purchased at the cost of an objective concept of

13 For a commentary see Gardner i 989: 339-56. An overview can be found in Gottschling 2003. the image. The opposition between model and copy becomes untenable if images are grasped as interminable processes of image making. Images, as one might put it, are not objective opus operatum but a specific modus operandi, a mode by which our object relations are constituted.

Image-making proceeds from seeing in the same way that narrative does from doing. As we saw, it is impossible to separate perception from the insight and knowledge it occasions or mediates. What is really significant plays out between the I and the other, but also between mental representation and intuition, perception and fiction.

Undoubtedly picturing something to oneself is an extremely ambivalent activity. Images can always be both petrifications and vitalisations. They open creative options of seeing differently while holding us prisoner, transcending the finite while fixing it in place. The imagination is at once void and plenitude, surplus and deficit, production and destruction, gaining and losing the world. The one cannot be without the other.

Not every imaginative seeing is a perception of possible aspects of something. There are cases like that of Don Quixote, who fails within the shared perceived world in the way infelicitous speech acts fail, making thus clear the chances and risks of a perceptual practice informed by imagination. Seeing windmills as giants, he undoubtedly commits an act of creative interpretation but not of possible aspect-seeing.

\section{Images hold us captive}

Wittgenstein was right to say that we are held captive by an image (Wittgenstein I 986: §II5).14 It is no coincidence that he makes this statement in the context of his new conception of language after the picture theory from the Tractatus (192 I). Linguistically, we are

14 This applies to both conceptual reification and phantasm. 
positively ensnared in images and narratives. 15 Every speech act re-invokes by citation things already said 16 and our perceptions are prefigured by countless images.

The affective power of these images cannot be overestimated and their imaginary component not only opens but also closes. There is no escaping this arrangement. Creativity, on the one hand, is the condition of the possibility of world disclosure by seeing while, on the other hand, harbouring the danger of losing the world.

I should have shown that there is no reason to replace the notion of pure seeing with one of pure interpretation. In the nexus of perception and imagination the one is not reducible to the other. There can be neither mere perception providing objective representations nor can perception be pure invention.

The aesthetic liberties inherent in aisthetic world disclosure interact with the social practice of a given epoch. The ways of seeing are therefore never entirely arbitrary. When they succeed or miscarry, then not because they are true or false in essence but because they count as capable or incapable of being adopted, regardless of justification.

The practical ramifications of perceptual world disclosure are graspable in the normative and existential significance of seeing on the personal and interpersonal levels: personally in the

15 Wilhelm Schapp ( I 976: ch. 4 and passim) places more emphasis than other narrative theories on the process of self-understanding by means of language as entanglement. However, the author reduces the relation between stories and images basically to one of illustration. On this account, images have the derivative function of making the story easier to understand. They are not recognised as a proper form of story-making.

16 See Krämer (200r: 259) on Judith Butler's conception of performative speech acts: 'What constitutes its performativity is not that it is an individual speech act, but rather that it evokes past speech acts in the manner of citation.' individual dispositions to ways of seeing conditioned by habitus and world image; interpersonally in the meaning of being visible for the development of self and self-consciousness.

\section{Normative seeing}

The power to see and be seen by other persons extends from acts of normative identity attribution to acknowledgement. The way people disclose the world is specific to their personality, to their moral disposition. Individual inclinations to judge and censure, prejudices, biases and personal preferences condition what and how we can see.

World-images in the sense sketched above of a normative background to speech, perception and action are at once prerequisites and products of perceptive-fictive world disclosure. Instead of speaking of world-images we could speak of the world views ${ }^{17}$ involved in mindset, patterns of behaviour and common normative orientation. Such world-images are in any case evaluative presuppositions often accompanied by conflicting validity claims, and have already preconfigured vision before it is directed at the world. They are thus the conditions of possibility of creative and conventional world disclosure.

If, for example, in the r93os the sight of a woman smoking in public was seen as a repulsive common annoyance (Cason r 930), comparable only to the sight of someone picking their teeth, this not merely bears witness to the curious attitudes of the times, but it is evidence of how closely seeing is linked to ways of seeing.

Admittedly, the way smoking is regarded in health and fitness discourses goes beyond aisthesis. The concrete sight of a smoking woman, however, does not. This sight and the emotions it is obviously able to stir up are very much a

17 See Karl Jaspers (I 994), who divided world views into sensible-spatial, psychic-cultural and metaphysical. 
question of seeing, and indeed a type of seeing that is, in practice, not independent of evaluative perspectives. It is thus a seeing that cannot be performed without being a way of seeing.

Such normative constructions could be described as the narrative constitution of reality, since narrative framing determines how emotion-based perceptual patterns are established. Using the example of eating a cake, Charles Taylor shows how a person's eating behaviour can be embedded in totally different interpretive frameworks according to whether or not the narrator invokes cholesterol and carbohydrates or qualities of self-control and abstinence (Taylor I $985: 20$ ). The salient point here is the way such narratives begin with perceptions: how I literally and concretely see something determines my possibilities of world disclosure.

\section{Seeing each other}

What is seeing, when people see each other, when we are visible and being looked at? Human visibility is necessarily social visibility, since we are visible in a purely physiological way only for instruments, not for other people. With our partly involuntary and partly chosen outer image we show ourselves to the others and offer ourselves to be perceived by them. Every selfrepresentation is an appeal to be seen and understood in a certain way, is mask or face. Looking at another, taking them into view, is fundamentally different from looking at an object. The characteristic simultaneity of seeing and being seen, the dimension of appealing-to and demanding-from, the character of encounter, all make interpersonal seeing a special case of visual perception.

The power of the gaze to constitute identity was sharply delineated by Sartre in a way exemplary for what I called instrumental seeing. Emmanuel Lévinas, on the contrary, has shown how we cannot see a human face as an arbitrary object, developing the ethical paradigm of self-purposive seeing.
The gaze can become an instrument of domination, as Sartre puts it. Emmanuel Lévinas, on the other hand, conceives of it as exteriority. While Sartre sees the I as objectified by the other, the seeing I in Lévinas is affected by an exteriority of the other that I cannot assimilate. In Sartre the other looks at me with a powerful 'evil eye'. In Lévinas the speaking face imperatively summons me to a responsibility I cannot rescind. Where Sartre speaks of subjugation, Lévinas speaks of responsibility. Sartre's other is the unconditional power that will disempower me unless I disempower it first. Lévinas's other is the unconditional alterity that disempowers me if I attempt to gain power over it (Sartre I 992: 340-40I; Lévinas r969). But both authors, despite their insights, tend toward dividing and ranking acts of the consciousness participating in seeing, thereby falling back into the subjectobject dichotomy. This entraps them inevitably in all the difficulties that the concept of seeing as practice evades. They separate sensibility and meaning, response and construction and take only one side of the two poles between which - as I hope to have shown - seeing takes place. As a practice, seeing takes place in contexts of social visibility and is based on being visible in a physiological sense and being seen as the subject of perceptual and fictitious gazes. Just as blushing with shame or turning pale with anger can hardly be regarded as 'purely physiological' reactions, psychic dispositions manifest physiologically. As reductionist as the assumption of purely physiological seeing is, the notion that people can be visible in a purely physiological sense is just as unacceptable.

The general structure of the way identity is constituted by social visibility can be differentiated from diverse points of view. It has aspects in socio-philosophical, psycho-philosophical, psychoanalytic, psychological, gender and power studies extending far beyond the purview of a theory of perception. Michel Foucault's theory of the panopticon or Jacques Lacan's notion 
of the gaze as object of desire. Judith Butler's theory of gendered performatively generated subjectivisation and George Herbert Mead's explanations of social identity constitution both belong to the broader context of seeing in relation to personal acknowledgement (Foucault I 995: I95 and passim; Lacan I 978; Butler I 997; Mead i959).

The ability to see oneself with the eyes of another is fundamental to generating social identity. It must be added that it is of course also the way the self is determined by the gaze of others. The way we appear to others determines who or what we are (Winnicott 1993: 128-35; Pines I 985: 2I I-3I).

However, for better or for worse, it is only in and through the gaze of the other that a self-image can develop. The self is given to itself through its visibility for others and so it can just as easily lose itself in the process.

The simultaneity of seeing and being seen constitutes a self-relationship. The I differs from itself and is at once identical with itself. In contrast, the gaze of the other works like an active mirror, affecting the spatial-temporal encounter between ego and alter. The gaze is a performance that founds or destroys, begins or ends something, attributing a particular form to the I gazed at while robbing it of other possible forms. It is at once a sensory and mental encounter with the power to constitute the I. Whether social conditioning and normatising, repressive sanctioning or the proverbial penetrating gaze that can be felt in the back, there is no principled difference in the constitution of subjectivity. A look can move us or it can bowl us over, the gaze can be objectifying, desirous, aggressive, disinterested or menacing; it is always the medium by which an image of the self, the other and the situation is constituted.

Translation by Steven Black
Prof. Dr Eva Schürmann holds the Chair for Philosophical Anthropology and Philosophy of Culture at the University of Magdeburg. In 2000, she published her doctoral thesis under the title Erscheinen und Wahrnehmen ('Appearing and Perceiving'). In 2009, she became Professor for Cultural Philosophy and Aesthetics at

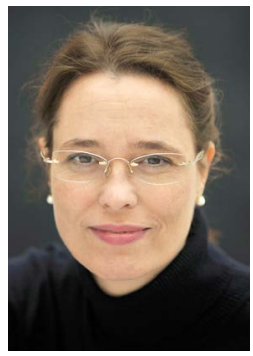
the HAW Hamburg. For her book Sehen als Praxis ('Seeing as Practice', Suhrkamp 2008) she was awarded the Science Prize of the Aby-WarburgStiftung in 2014. Since October 2015 she has been co-editor of the Allgemeine Zeitschrift für Philosophie, a peer-reviewed philosophical journal <http://www. iphi.ovgu.de/schuermann>.

\section{References}

Blumenberg, Hans, 2010. Paradigms for a Metaphorology (Ithaca, NY, Cornell University Press)

Butler, Judith, I 997. The Psychic Life of Power: Theories of Subjection (Stanford University Press)

Cason, Hulsey, I 930. 'Common annoyances: a psychological study of every-day aversions and irritations', Psychological Monograms, $40(2)$, pp. I-2 I 8

Cassirer, Ernst, 1944. An Essay on Man: An Introduction to a Philosophy of Human Culture (New Haven, CT, Yale University Press)

Coleridge, Samuel Taylor, I 8 I 7 . Biographia Literaria, or, Biographical Sketches of $M y$ Literary Life and Opinions (New York, Kirk and Mercein)

Davidson, Donald, I 997. 'Seeing through language', Thought and Language, ed. John Preston (Cambridge University Press), pp. I 5-27

Elkins, James, 200 I. Pictures and Tears (London, Routledge)

Fichte, Johann-Gottlieb, I 889. Science of Knowledge (London, Trübner \& Co.)

Fischer-Lichte, Erika, Christian Horn, Matthias Warstatt, and Sandra Umathum (eds), 200 I. Wabrnehmung und Medialität (Tübingen, Francke)

Foerster, Heinz von, I985. Sicht und Einsicht (Braunschweig, Vieweg)

Foucault, Michel, I 995. Discipline and Punish: The Birth of the Prison (New York, Vintage Books)

Gardner, Howard, I 989. Dem Denken auf der Spur. Der Weg der Kognitionswissenschaft (Stuttgart, Klett-Cotta) 
Gerth, Sebastian, 20 6. 'Mentale Bilder als visuelle Form der Weltrepräsentation?’, IMAGE, 24, pp. 5-49

Gottschling, Verena, 2003. Bilder im Geiste. Die Imagery-Debatte (Paderborn, Mentis)

Humboldt, Wilhem von, I 973. Schriften zur Sprache (Stuttgart, Reclam)

Husserl, Edmund, 2006. Phantasy, Image Consciousness, and Memory (1898-1925) (Heidelberg, Springer)

Iser, Wolfgang, I 991. Das Fiktive und das Imaginäre. Perspektiven literarischer Anthropologie (Frankfurt am Main, Suhrkamp)

Jaspers, Karl, I 994. Psychologie der Weltanschauungen (München, Piper)

Jonas, Hans, I973. 'Homo pictor. Von der Freiheit des Bildens', Organismus und Freiheit, ed. Hans Jonas (Göttingen, Vandenhoeck \& Ruprecht), pp. 226-47

Kamper, Dietmar, I98 I. Zur Geschichte der Einbildungskraft (München, Carl Hanser)

— I998. 'Bild', Anthropologie, ed. Gunter Gebauer (Leipzig, Reclam), pp. 203-I3

Kant, Immanuel, I 999. Critique of Pure Reason (Cambridge University Press)

2002. Critique of the Power of Judgment (Cambridge University Press)

Koch, Gertrud (ed.), I 995. Auge und Affekt. Wabrnebmung und Interaktion (Frankfurt am Main, Fischer)

Konersmann, Ralf, I 99 I. Die Metapher des Subjekts (Berlin, Fischer)

Kosslyn, Stephen Michael, I980. Image and Mind (Cambridge, MA, Harvard University Press)

Krämer, Sybille, 200 I. Sprache, Sprechakt, Kommunikation. Sprachtheoretische Positionen des 20. Jahrbunderts (Frankfurt am Main, Suhrkamp)

Lacan, Jacques, I978. 'Of the gaze as objet petit a', The Four Fundamental Concepts of Psychoanalysis: The Seminar of Jacques Lacan (New York, W.W. Norton \& Co.), pp. 67-i i 9

Lévinas, Emmanuel, 1969. Totality and Infinity (Pittsburgh, PA, Duquesne University Press)

Lyotard, Jean-François, I 988. The Differend: Phrases in Dispute (Minneapolis, University of Minnesota Press)

McGinn, Colin, 2004. Mindsight: Image, Dream, Meaning (Cambridge, MA, Harvard University Press)

Mead, George Herbert, I959. Mind, Self E Society: From the Standpoint of a Social Behaviorist (The University of Chicago Press) Mitchell, Wilhelm John Thomas, I 986. Iconology:
Image, Text, Ideology (The University of Chicago Press)

Pines, Malcom, I985. 'Mirroring and child development', Psychoanalytic Inquiry, 5, pp. 2 II -3 I

Sachs-Hombach, Klaus (ed.), I 995. Bilder im Geiste (Amsterdam, Rodopi)

Sartre, Jean-Paul, I 992. Being and Notbingness (New York, Washington Square Press)

2004. The Imaginary: A Phenomenological Psychology of the Imagination (London, Routledge)

Schäfer, Gerd, and Christoph Wulf (eds), I 999. Bild, Bilder, Bildung (Weinheim, Beltz)

Schapp, Wilhem, I976. In Geschichten verstrickt (Wiesbaden, B. Heymann)

Schürmann, Eva, 2008. Sehen als Praxis (Frankfurt am Main, Suhrkamp)

Taylor, Charles, I 985 . 'What is human agency?', Philosophical Papers (Cambridge University Press)

Winnicott, Donald Woods, I 993. 'Die Spiegelsfunktion von Mutter und Familie in der kindlichen Entwicklung', Vom Spiel zur Kreativität, ed. Donald Woods Winnicott (Suttgart, Klett-Cotta), pp. I 28-35

Wittgenstein, Ludwig, I986. Philosophical Investigation (Oxford, Blackwell) 